WIDER Working Paper 2014/116

\title{
The impact of conditional cash transfer programmes on household work decisions in Ghana
}

Eric Ekobor-Ackah Mochiah, Robert Darko Osei, and Isaac Osei Akoto*

September 2014 
Abstract: A cash transfer programme 'Livelihood Empowerment against Poverty' has been implemented with the aim of addressing poverty and vulnerability in Ghana. This study looks at the impact of this conditional cash transfer programme on households' supply of labour for agriculture, paid employment, and non-farm enterprise. We used a difference-in-difference approach to examine the effects of the programme on 3,008 households to learn about their labour supply decisions. We find that the cash transfer leads to a reduction in agricultural labour supply but increases that of paid employment. A careful look at the subsequent targeting of beneficiaries is recommended.

Keywords: poverty reduction, cash transfers, social protection, household decision, labour supply, impact evaluation

JEL classification: I380

\section{List of acronyms}

CCT conditional cash transfer

GLSS5 Ghana Living Standard Survey (5)

LEAP Livelihood Empowerment against Poverty

MESW Ministry of Employment and Social Welfare

MDA ministries, departments and agencies

MOU memorandum of understanding

NHIS National Health Insurance Scheme

NSPS National Social Protection Strategy

NYEP National Youth Employment Programme

OVC orphans and vulnerable children

SSNIT Social Security and National Insurance Trust

*All authors ISSER, University of Ghana, corresponding author Eric Ekobor-Ackah Mochiah: ghostphase1@yahoo.com

This paper has been presented at the UNU-WIDER 'Conference on Inclusive Growth in Africa: Measurement, Causes, and Consequences’, held 20-21 September 2013 in Helsinki, Finland.

Copyright (C) The Authors 2014

ISSN 1798-7237 ISBN 978-92-9230-837-7

Typescript prepared by Liisa Roponen for UNU-WIDER.

UNU-WIDER gratefully acknowledges the financial contributions to the research programme from the governments of Denmark, Finland, Sweden, and the United Kingdom.

The World Institute for Development Economics Research (WIDER) was established by the United Nations University (UNU) as its first research and training centre and started work in Helsinki, Finland in 1985. The Institute undertakes applied research and policy analysis on structural changes affecting the developing and transitional economies, provides a forum for the advocacy of policies leading to robust, equitable and environmentally sustainable growth, and promotes capacity strengthening and training in the field of economic and social policy-making. Work is carried out by staff researchers and visiting scholars in Helsinki and through networks of collaborating scholars and institutions around the world.

UNU-WIDER, Katajanokanlaituri 6 B, 00160 Helsinki, Finland, wider.unu.edu

The views expressed in this publication are those of the author(s). Publication does not imply endorsement by the Institute or the United Nations University, nor by the programme/project sponsors, of any of the views expressed. 


\section{Introduction}

The most popular policy tool used in the last decade in developing countries to increase human capital has been the conditional cash transfer programme, which provides cash payments to households conditional on regular school attendance and visits to health clinics. Many governments implemented experimental frameworks to assess the impacts of conditional cash transfers on employment, schooling, and health among poor eligible households (Progresa in Mexico and PRAF in Honduras, among others). Conditional cash transfers have achieved quantified success in reaching the poor and bringing about short-term improvements in consumption, education, and health (Schultz 2004; Gertler 2004; Rawlings and Rubio 2003), although most of the literature has focused on mean impacts.

Over the past decade Ghana has made impressive progress in stimulating economic growth, reducing poverty, and improving governance. Indeed, international assessments frequently herald Ghana as a shining example of development not only in West and Central Africa, but on the African continent more broadly. But, there is a broader concern that economic growth has been prioritized at the expense of social service provision and quality, and tackling the problem of social exclusion.

Nonetheless, since the millennium, major social protection interventions complemented by the National Social Protection Strategy (NSPS) have been taken to address poverty and vulnerability in Ghana, including the Social Security and National Insurance Trust (SSNIT) which encompasses a pension scheme, school feeding programme, capitation grant (public primary schools), national health insurance scheme (NHIS), national youth employment programme (NYEP), social welfare programmes, supplementary feeding programmes, integrated agriculture support programme, microfinance schemes, free maternal and post natal services for pregnant and lactating mothers, and finally the Livelihood Empowerment Against Poverty (LEAP) which is a cash transfer programme.

There are now signs that some of these measures, along with the general improvement in the standard of living, are beginning to have a significant impact, including increased enrolment and healthcare. Despite the growing popularity of conditional cash transfers (CCTs), some policy makers remain concerned that these programmes create disincentives to work. Even though several studies have found contrary views to this assertion on CCTs in countries like Mexico, Nicaragua, and Brazil, there is still the need to assess the situation with regard to Ghana's LEAP programme concerning the hours worked by households. This creates the motivation to examine how these specific objectives pertain to Ghana and its LEAP programme.

Specifically, the objectives of this paper are to find out whether:

- The conditional cash transfer scheme has in general increased the probability of households to work;

- The hours worked on farm (agriculture) and off-farm (non-farm enterprises) have increased with the CCT scheme;

- Working hours for paid employment (employment opportunities) in the households have increased with the LEAP programme; and

- CCTs affect the number of hours worked by men differently from women in households.

Section 2 looks at some evidence from studies on conditional cash transfer schemes. Section 3 follows with the methodology. Section 4 presents the results which are made up of descriptive 
statistics and results from the regression. Section 5 concludes by observing that the LEAP programme decreased total labour supply for agriculture but had the opposite impact for paid employment. However there was no impact of the programme on labour supply for non-farm enterprises. Generally, unearned income affected work decisions negatively. The section further offers some recommendations for future targeting and implementation.

\section{Evidence from studies of conditional cash transfer programmes}

\subsection{General effects of conditional cash transfer programmes}

Cash transfer schemes, mostly for developing countries, have a varying degree of impact on various aspects of human living. Some of these include their effect on children through nutritional and health benefits like health insurance, educational advantages through the opportunities for children to be in school; the effect on savings and investment; the effect on consumption of 'temptation' goods; effects on labour supply; and the effect on inter- and intra-household conflicts.

Looking specifically at the effect on children, studies by Duflo (2003) and Aguero et al. (2007) find similar effects of the cash transfer support targeted to South African women and their children. The scheme boosted the heights of young children, but specifically increased the weight-for-height and height-for-age of young girls in the household. Under Equador's Bono de Desarrollo Humano, Paxson and Schady (2007) find that children of poor mothers who received cash transfers benefitted from the scheme in terms of physical, socio-emotional, and cognitive development. An increase in expenditure on children was seen by Attanasio and Mesnard (2006) in Colombia's Familias en Acción. Some positive effects of the Red de Proteccion Social of Nicaragua included the drop in child labour, reduced stunting and increased height-for-age (Maluccio and Flores 2005). Cunha (2010) finds that nutritionally Mexican households receiving cash transfers had its children increase their intake of micro-nutrients like zinc, iron, and vitamin C.

In terms of education, according to Handa et al. (2013), the LEAP programme of Ghana increased school enrolment by 7 percentage points for secondary school-aged children, reduced grade repetition in both primary and secondary school-aged children, and decreased absenteeism by 10 percentage points. Also with respect to Ghana's LEAP, they observe that there had been no impact on curative care-seeking but find positive impact on preventive care among girls aged 0-5. Furthermore Handa et al. (2013) note gender impacts on children: higher participation in the National Health Insurance Scheme (NHIS) among girls aged 0-5, higher secondary school enrolment for boys, and greater school attendance for girls. Food security and happiness impacts were higher for female-headed households.

With regard to the effect of cash transfer programmes on savings and investment, Duflo (2003) estimates that about 53 per cent and 82 per cent of cash transfer were saved, respectively, by men and women in South Africa relative to 50 per cent for non-pension income. In Colombia's Familias en Acción, Attanasio and Mesnard (2006) estimate that 50 per cent of the cash received was saved. According to Rubalcava et al. (2004) in the Mexico's Progresa, 50 per cent of the transfer was saved. In Ghanaian households under the LEAP programme, the likelihood of holding savings as well as gift-giving had increased, also the cash transfer (Handa et al. 2013) impacted on debt repayment. In Mexico's Progresa, Gertler et al. (2006) estimate that 12 per cent of the transfers received are invested in assets including land. Other studies have recorded evidence on the rate of return on investments 
made by households participating in cash transfer programmes. Household incomes increased, as observed by Sadoulet et al. (2001) by a factor between 1.5 and 2.6 times the transfer received, which is an indicator of good investment.

Studies on the consumption of 'temptation' goods show varying results. Slater and Mphale (2008) observe no significant increase in expenditures on alcohol in an evaluation of a pilot cash transfer scheme in Lesotho. In an Oxfam pilot cash transfer in Vietnam, Humphries (2008) finds no reports on spending on alcohol or gambling. Attanasio and Mesnard (2006) find that Colombia's Familias en Acción conditional cash transfer programme had no effect on tobacco, alcohol, and entertainment. On the other hand, a marginally significant negative effect was found in the share of the household budget for alcohol and tobacco in Mexico's Progresa cash transfer scheme. According to Cunha (2010), in Mexican households about 1.8 per cent of the cash transfer received was spent on alcohol while the amount spent on tobacco consumption decreased by 0.8 per cent. Handa et al. (2013) report no consumption impact from the LEAP in Ghana.

Tensions arise mainly from the procedures for selecting eligible households for the cash transfer. Brewin (2008) in evaluating Kenya's cash transfer pilot, 'Concern', received anecdotal reports that tension between different tribes diminished, as families from different tribes met on common grounds take receipt of the cash transfer. Studies by Slater and Mphale (2008), Humphries (2008), and 'Concern' worldwide (2007), report similar effects of cash transfers reducing conflict within households. However, some have raised concerns in Ghana about the targeting of beneficiaries, as it has been labelled as benefiting only political party members.

\subsection{Effects on household labour supply}

Most studies report no effect of cash transfers on the labour supply of adult household members. Skoufias and Maro (2008) assess the impact of Mexico's Progresa programme on poverty and adult work incentives. The research draws on survey data collected from 24,000 households across seven states, between 1997 and 1999. Some key findings were that the programme had no significant effect on adults' choices regarding work, and this was true for both eligible and non-eligible households. Some programme beneficiaries might have used a part of their transfer, at least initially, to seek salaried work and reduced their participation in low-paid work in family businesses. Progresa participants also did not use their transfers to 'buy' more leisure time even though the programme led to a substantial reduction in existing poverty levels. Skoufias and Maro conclude that Progresa's cash transfers have not discouraged people from working.

Maluccio and Flores (2005) find no effect on the labour supply for Nicaragua's Red de Protección Social conditional cash transfer scheme. Several papers have examined the labour supply effects of an important pension scheme in South Africa. For example, Bertrand et al. (2003), using cross-sectional data, estimate that pension receipt substantially lowers the labour market participation of workingage adults in the household. Using the same data, Posel et al. (2006) show that while participation by resident adults is lower, adult women are significantly more likely to migrate out of the household in search of work. They also conclude that receipt of a pension has a significant positive impact on the job search of unemployed household members.

Ardington et al. (2009) use a new dataset that tracks over time both households and migrants and find a net positive effect of pensions on labour supply. As they note: 
... large cash transfers to the elderly lead to increased employment among primeaged adults, which occurs primarily through labour migration. The pension's impact is attributable to the increase in household resources it represents, which can be used to stake migrants until they become self-sufficient, and to the presence of pensioners who can care for small children, which allows prime-aged adults to look for work elsewhere (Ardington et al. 2009: 22).

Ferro et al. (2010) find that the Bolsa Escola CCT programme in Brazil increased mothers' and fathers' probability of participating in labour force work. Again under the Mexican Progresa programme, urban parents increased their probability of working in the labour force by 3 per cent. With regard to the parents' labour status, work decisions of mothers and fathers were not affected by the transfers, mainly it seems because their programme eligibility was determined only once for the subsequent three years and was not regularly re-evaluated (Skoufias and Parker 2001).

In South Africa, households receiving an old age pension have labour force participation rates of 11-12 per cent higher than non-eligible households, as well as employment rates 8-15 per cent higher (Samson et al. 2004). In Brazil, adults in beneficiary households in the Bolsa Familia programme had a 2.6 percentage points higher labour market participation rate than adults in households not in the programme. This effect differed according to gender. Women in beneficiary households had participation rates 4.3 percentage points higher than women in non-participating households (Oliveira et al. 2007).

Handa et al. (2013) observe for Ghana that in households with four members or less, the LEAP programme was seen to have a positive effect on men's own labour supplied to the farm and hired male farm-workers. This, they say, was consistent with the payment structure of the programme where average value of the transfer was much larger for households' with less members.

\subsection{Livelihood empowerment against poverty in Ghana}

The LEAP programme is a social cash transfer scheme which provides cash and health insurance to extremely poor households across Ghana to alleviate short-term poverty and encourage long-term human capital development. Among other things, the LEAP programme is aimed at improving basic consumption of the beneficiary households by increasing children's enrolment, attendance and retention in school, as well as improving livelihood income-earned activities like block farming. LEAP started as a trial phase in March 2008 with 1,654 beneficiary households in 21 districts, and then began expanding gradually in 2009 and 2010. As of June 2010 it had reached approximately 35,000 households across Ghana with an annual expenditure of approximately US $\$ 11$ million. By March 2012, 68,000 households from 100 districts were benefiting from LEAP. The budgetary allocation for this number of households was GHф18 million for 2012. Beneficiary households in 2015 are expected to reach 165,000 (Daily Graphic 2012).

The scheme is fully funded from general revenues of the government of Ghana, and is the flagship programme of its NSPS. It is implemented by the Department of Social Welfare in the Ministry of Employment and Social Welfare (MESW). An exciting feature of LEAP is that apart from direct cash payments, beneficiaries are provided with free health insurance through the new NHIS which began in 2004-05. This is facilitated through a memorandum of understanding between the MESW and Ministry of Health; funds to cover enrolment in health insurance are transferred directly to the 
local health authorities who then issue health insurance cards to LEAP households. Continued receipt of cash payments from LEAP is conditional on this card.

LEAP provides social grants to beneficiaries chosen from extremely poor households in Ghana. It is intended to supplement the basic subsistence needs of the target groups and link them to complementary services. The constituents of the LEAP beneficiaries are the bottom 20 per cent of the country's mega poor households. Based on the fifth round of the Ghana Living Standards Survey (GLSS5) this 'poorest of the poor' group includes some 164,370 households. In the LEAP programme document, all these households were to be reached by the end of the fifth year. The target group includes subsistence farmers and fisher folk, extremely poor citizens above 65 years who are without any subsistence support as well as persons with severe disabilities without any productive capacity; care-givers of orphans and vulnerable children (OVC, particularly children affected by HIV/AIDS or with severe disabilities), incapacitated/extremely poor people living with HIV/AIDS and pregnant women/lactating mothers with HIV/AIDS. All beneficiaries in these categories must be from ultra-poor households. For some of the beneficiaries, mainly with respect to the OVC, the cash transfer is conditional. For the aged and severely disabled, it is unconditional.

Initial selection of households was done through a community-based process and was verified centrally with a proxy means test. The districts were selected from those with severest form of child labour based on data from the Ghana Statistical Service and in consultation with key ministries, departments and agencies (MDAs). Further consultations were held with communities and MDAs in the potential districts and this formed the basis of selecting the communities. Community committees were then asked to pick potential beneficiaries after which the assets, household characteristics, and demographic information were collected on these potential beneficiaries. Using this information, the Department of Social Welfare then undertook a wealth ranking selection upon which final beneficiaries were decided. The amount of the cash transfers ranged from $\mathrm{GH} \phi 8$ (US\$5.52) for one beneficiary to GH $15^{1}$ (US\$10.34) for four or more beneficiaries per month. This means that the amount that a household gets depends on the number of beneficiaries in that household.

According to the programme document, the amount of the cash transferred to beneficiaries was to be sufficient (about 15 per cent of the minimum wage as at 2007), to raise their livelihood without raising their income beyond the level that would encourage unemployment, create dependency, or benefit beneficiary households excessively compared to other income groups in the community. In other words, an amount that was considered to be adequate and acceptable. The amount was also compared to what pertained in other countries and was found to be within the range of what was paid elsewhere. The total cost for the LEAP by the end of the fifth year was estimated to be about GH 141 million, with the cost of administering the cash transfers to be about 12 per cent of the total. Women were considered to be the preferred care-givers and therefore recipients of the transfers because the probability of maximizing the impact at the household level is higher if the recipients were women (NSPS 2007).

\footnotetext{
${ }^{1}$ This conversion is based on March 2011 exchange rate of about US\$1 to GHф1.45. This amount, however, has been increased from GHф12 (US\$6.38) to GHф36 (US\$19.15) per beneficiary since July 2012 after the re-launch of the LEAP programme. This new conversion is based on the July 2012 exchange rate of US\$1 to GHф1.88.
} 
According to Handa et al. (2013) there were inconsistencies in the implementation of the LEAP. Over the 24-month evaluation period reviewed by Handa and co-authors, households received only 20 months' worth of payments. There was a long gap in payments to households in 2011. Payments were regular until May 2011 after which no payments were made for eight months. This was followed by a triple payment in February 2012 to settle arrears. Thus, LEAP households did not receive a steady, predictable flow of cash with which to smooth consumption. Handa et al. (2013) express concern about the implication of lump-sum payments on the consumption of beneficiary households. They believe that the lump-sum settlement in February 2012 may have been used for investment or savings rather than to smoothen current consumption. Nevertheless, programme implementation was impressive for the NHIS, with 90 per cent of the LEAP households having at least one member in NHIS in the follow-up survey.

The value of the transfer was also an issue raised by the team of programme evaluators. Handa et al. (2013) point out that in Ghana LEAP's contribution makes up only 11 per cent of consumption expenditure which is very low relative to at least 20 per cent of other successful cash transfer programmes. They also state that the cumulative inflation over the period in question was 19 per cent. This eroded the value of the transfer so that at the time of the follow-up survey, the value of the transfer was about 7 per cent of consumption. After an increase in the transfer value by the government of Ghana, Handa et al. (2013) estimate that the new value corresponded to 21 per cent of consumption, but they also suggest that the transfer value should be pegged with the inflation rate to maintain its real value.

\section{Methodology}

\subsection{Sampling technique and sample size}

The evaluation strategy of the LEAP programme entailed a longitudinal propensity score matching (PSM) design. One is able to attribute changes over time to the intervention by permitting for the construction of a counterfactual under the PSM strategy, through a matched comparison group, and to follow this group over the same observation period. Baseline data were collected (out of 700 households ${ }^{2}$ ) from future beneficiaries in the first quarter of 2010. A comparison group of 'matched'

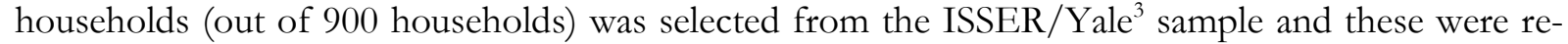
interviewed in the first quarter of 2012 along with LEAP beneficiaries in a follow-up survey to measure changes in outcomes across treatment and comparison group (control).

\subsection{Econometric model}

With the above sampling strategy, we examine whether there is any significant effect of the cash transfer on the hours worked between the treatment group and the control group. This approach helps to achieve the selected objectives of finding out the impact of the cash transfer on the hours worked by the household in total, for agriculture, for paid employment, and non-farm enterprises. To do this, we adopt a difference-in-difference method, which has been vastly used in the literature

\footnotetext{
${ }^{2}$ After the follow-up survey, households with data for both baseline and follow-up totalled 858 for the control group (ISSER/Yale sample) and 646 for the treatment group (LEAP beneficiaries).

${ }^{3}$ Larger nationally representative sample of 5,009 households was surveyed as part of a research study conducted by ISSER and Yale University (USA).
} 
to account for differences in outcome variables in randomized experiments. The relevant equation estimated is of the form:

$$
Y_{\text {it }}=\beta_{0}+\beta_{1} T_{\text {it }}+\beta_{2} A_{i t}+\beta_{3} T_{\text {it }} A_{i t}+\beta_{4} X_{i t}+\varepsilon_{\text {it }}
$$

where $Y_{i t}$ is the number of hours worked by the household $i$ at time $t(t=1,2), X_{i t}$ is a vector containing covariates which may influence the number of hours worked by a household. $T_{\text {it }}$ is a trend variable which equals to 1 in the period after which the treatment intervention was administered and zero (0) for the baseline period. $A_{\mathrm{it}}$ is dummy variable which equals to 1 for all households in the treatment group and zero ( 0$)$ for the control group in both periods. $T_{\text {itt }} A_{i t}$ is an interactive variable. The coefficient of this interactive variable provides a measure of the effect of the intervention which is referred to as the difference-in-difference estimator and can be expressed as:

$$
\beta_{3}=\left(Y_{a 1}^{*}-Y_{c 1}^{*}\right)-\left(Y_{a 2}^{*}-Y_{c 2}^{*}\right)
$$

where $Y_{a 1}^{*}$ and $Y_{c 1}^{*}$ are the respective averages of the number of hours worked by households in the treatment and control groups in the baseline period and $Y_{a 2}^{*}$ and $Y_{c 2}^{*}$ are the corresponding averages for the second period. If the ' $\mathrm{X}$ ' covariates are assumed away in Equation 1, then the difference in the average hours worked between the treatment and the control before the intervention will be $\beta_{1}$ :

$$
\beta_{1}=\left(Y_{a 1}^{*}-Y_{c 1}^{*}\right)=\left(\beta_{0}+\beta_{1}\right)-\beta_{0}
$$

In the period after the intervention has taken place, the difference between the treatment and control groups can be expressed as:

$$
\beta_{1}+\beta_{3}=\left(Y_{a 2}^{*}-Y_{c 2}^{*}\right)=\left(\beta_{0}+\beta_{1}+\beta_{2}+\beta_{3}\right)-\left(\beta_{0}+\beta_{2}\right)
$$

The difference-in-difference is therefore expressed as follows:

$$
\beta_{3}=\left(Y_{a 1}^{*}-Y_{c 1}^{*}\right)-\left(Y_{a 2}^{*}-Y_{c 2}^{*}\right)=\left(\beta_{1}+\beta_{3}\right)-\beta_{1}
$$

\subsection{Variables generated and used}

Appendix Table A1 lists the variables used in this study. The variables can be grouped into household characteristics, beneficiary characteristics, and other characteristics. Among some of the applied household variables were income from the farm, from non-farm enterprises, paid employment income, other transfers into the household, health attributes such as whether members of the household could carry loads, agricultural land sizes, education variables of members, and others.

Under personal characteristics, dummy variables were used to capture various beneficiaries such as being widowed or handicapped. The beneficiary characteristics included the number of beneficiaries in a household. Other characteristics were the difference-in-difference variables like the treatment variable, the time variable and interaction of the treatment dummy, and the time dummy variables. 


\section{$4 \quad$ Discussion of results}

\subsection{Descriptive statistics}

This section presents the demographic characteristics of the surveyed households and their heads. Demographic characteristics presented include gender, educational attainment, marital status of the household head, and the household size. The average household size of the sample is also given. The tables are generated based on the households that completed the two waves of surveys.

\subsection{Demographic characteristics of household heads}

In all, majority of household heads are female (59.3 per cent for the treatment group versus 50.9 per cent for the control group) with 37.6 per cent married from the treatment group and 45.1 per cent from the control group. The majority of the heads of the treatment group are widowed (40.7 per cent) while this is true for only 26.6 per cent of the heads in the control group. The breakdown follows a similar trend as the programme targeting set-up, as most care-givers are female, and many beneficiaries are widows. In terms of level of education, about 53.1 per cent of household heads from the treatment group have no education relative to 43.6 per cent for their control counterparts. Only 2.7 per cent in the treatment group are educated above senior high school. The average household size for the surveyed households is 3.9 and 3.8, respectively, for the treatment and control households (Table 1).

Table 1: Distribution of the background characteristics of household heads

\begin{tabular}{|c|c|c|c|c|c|}
\hline & Treatment & Control & & Treatment & Control \\
\hline Sex of household head & & & Household size & & \\
\hline Male & 40.7 & 49.1 & 1 & 18.3 & 19.4 \\
\hline Female & 59.3 & 50.9 & $2-3$ & 32.7 & 32.8 \\
\hline Marital status of household head & & & $4-5$ & 21.8 & 26.5 \\
\hline Married & 37.6 & 45.1 & $6-7$ & 17.6 & 13.5 \\
\hline Consensual union & 3.7 & 7.4 & $8-9$ & 7.3 & 4.9 \\
\hline Separated & 3.4 & 4.4 & $10+$ & 2.3 & 3.0 \\
\hline Divorced & 9.2 & 12.5 & & & \\
\hline Widowed & 40.7 & 26.6 & Educational level of head & & \\
\hline Never married & 5.3 & 4.0 & No education & 53.1 & 43.6 \\
\hline Betrothed & 0.1 & 0.0 & Senior high school and below & 44.2 & 51.9 \\
\hline Mean household size & 3.9 & 3.8 & Above senior high school & 2.7 & 4.6 \\
\hline
\end{tabular}

Source: Authors' compilation.

Table 2 gives the annual average labour hours per household. The overall average labour hours for agriculture, paid employment, and non-farm enterprises is 1,041 and 1,452 hours for the treatment and control households, respectively, in the baseline. During the follow-up, the number of hours worked by the treatment households decreased to 1,114 hours while that of the controlled households increased to 1,466 hours. The p-values show no difference in the hours worked for paid employment and non-farm enterprises in the baseline. However, there is a significant difference in the hours worked in agriculture. 
Table 2: Annual average labour hours per household

\begin{tabular}{|c|c|c|c|c|c|c|}
\hline \multirow[t]{2}{*}{ Labour hours } & \multicolumn{2}{|c|}{ Baseline } & \multirow{2}{*}{$\begin{array}{c}\text { T-test } \\
\text { P-value }\end{array}$} & \multicolumn{2}{|c|}{ Follow-up } & \multirow{2}{*}{$\begin{array}{l}\text { T-test } \\
\text { P-value }\end{array}$} \\
\hline & Treatment & Control & & Treatment & Control & \\
\hline Agriculture & 306.1 & 671.2 & 0.000 & 349.6 & 550.5 & 0.000 \\
\hline Paid employment & 95.1 & 106.6 & 0.672 & 108.4 & 78.9 & 0.171 \\
\hline Non-farm enterprises & 640.3 & 673.9 & 0.693 & 655.9 & 836.2 & 0.097 \\
\hline Total & 1041.5 & 1451.7 & 0.000 & 1113.8 & 1465.7 & 0.003 \\
\hline
\end{tabular}

Source: Authors' compilation.

\subsection{Regression results}

The difference-in-difference results reported in Table 3 (columns 1 and 2, columns 3 and 4, columns 5 and 6, and columns 7and 8) represent the logs of households' overall labour supply, labour supply for agriculture, labour supply for paid employment, and labour supply for non-farm enterprises. With reference to the first objective of the paper, the impact of the conditional cash transfer on labour supply is significant at 10 per cent, hence households that received the transfer relative to those that did not, reduced their labour supply by 39.8 per cent (Treattime in Equation 1) as opposed to the conclusion by Skoufias and Maro (2008) that Mexico's Progresa cash transfers have not discouraged people from working. However, when other variables are controlled for in Equation 2, the variable loses its significance and, as many studies have suggested, conditional cash transfer programmes have had no influence on labour decisions. The total labour supply under Equation (1) and (2) is the sum of labour supply for agriculture, paid employment, and non-farm enterprises.

Variables that increased household total labour supply were annual income from paid employment (ILabannualinc: 38.9 per cent), sales from non-farm enterprises (IEnt_sales1: 34.8 per cent), income from agriculture (lagricincome: 21.9 per cent), the good health status of household members (cancarryload: 84.5 per cent), larger size of cultivated land (lsize: 127.4 per cent), and larger household size (hhsize: 10.1 per cent). On the other hand, non-institutional transfers into households reduced total labour supply by 9.5 per cent while handicapped beneficiaries reduced their labour supply by 50.8 per cent. The marginal impact attributable to transfers into households for those that received the LEAP benefits reduced total labour supply by 10.1 per cent. Generally, a healthy household with some male composition, a larger land size for cultivation and more household members increased labour supply for all activities being studied.

Table 3: Difference-in-difference regression for household labour hours in total and for agriculture, paid employment and non-farm enterprise

\begin{tabular}{|c|c|c|c|c|c|c|c|c|}
\hline \multirow[b]{3}{*}{ Variables } & \multicolumn{2}{|c|}{ All } & \multicolumn{2}{|c|}{ Agriculture } & \multicolumn{2}{|c|}{ Paid employment } & \multicolumn{2}{|c|}{ Non-farm enterprise } \\
\hline & Eqn1 & Eqn2 & Eqn3 & Eqn4 & Eqn5 & Eqn6 & Eqn7 & Eqn8 \\
\hline & \multicolumn{2}{|c|}{ ITotallabhrs } & \multicolumn{2}{|c|}{ ITotagriclabhrs } & \multicolumn{2}{|c|}{ ITpaidemphrswk } & \multicolumn{2}{|c|}{ ITotlabhrs_ent } \\
\hline Treatdum & $\begin{array}{l}-0.823^{\star \star \star} \\
(0.153)\end{array}$ & $\begin{array}{l}-0.070 \\
(0.117)\end{array}$ & $\begin{array}{l}-0.914^{\star \star \star} \\
(0.149)\end{array}$ & $\begin{array}{l}-0.111 \\
(0.111)\end{array}$ & $\begin{array}{l}-0.075 \\
(0.085)\end{array}$ & $\begin{array}{l}-0.202^{\star *} \\
(0.086)\end{array}$ & $\begin{array}{l}-0.099 \\
(0.164)\end{array}$ & $\begin{array}{c}0.042 \\
(0.165)\end{array}$ \\
\hline Time2 & $\begin{array}{l}0.659 * * * \\
(0.147)\end{array}$ & $\begin{array}{l}0.540^{* *} \\
(0.245)\end{array}$ & $\begin{array}{l}0.564^{\star * *} \\
(0.143)\end{array}$ & $\begin{array}{l}0.678^{\star * *} \\
(0.230)\end{array}$ & $\begin{array}{l}-0.052 \\
(0.082)\end{array}$ & $\begin{array}{c}0.200 \\
(0.177)\end{array}$ & $\begin{array}{l}0.366^{\star *} \\
(0.158)\end{array}$ & $\begin{array}{l}-0.006 \\
(0.296)\end{array}$ \\
\hline Treattime & $\begin{array}{l}-0.398^{\star} \\
(0.216)\end{array}$ & $\begin{array}{c}0.263 \\
(0.264)\end{array}$ & $\begin{array}{l}-0.489^{\star \star} \\
(0.211)\end{array}$ & $\begin{array}{l}-0.074 \\
(0.249)\end{array}$ & $\begin{array}{c}0.160 \\
(0.120)\end{array}$ & $\begin{array}{c}0.315^{\star} \\
(0.191)\end{array}$ & $\begin{array}{l}-0.218 \\
(0.232)\end{array}$ & $\begin{array}{c}0.110 \\
(0.371)\end{array}$ \\
\hline ILabannualinc & & $0.389^{\star \star \star}$ & & $-0.121^{\star \star \star}$ & & & & $-0.140^{\star \star \star}$ \\
\hline
\end{tabular}




\begin{tabular}{|c|c|c|c|c|c|c|c|c|}
\hline & & $(0.026)$ & & $(0.024)$ & & & & $(0.036)$ \\
\hline HHhasnonfarm & & $\begin{array}{c}0.287 \\
(0.184)\end{array}$ & & $\begin{array}{c}0.044 \\
(0.174)\end{array}$ & & $\begin{array}{l}-0.223^{\star} \\
(0.133)\end{array}$ & & \\
\hline IEnt_sales1 & & $\begin{array}{l}0.348^{* \star *} \\
(0.018)\end{array}$ & & $\begin{array}{l}-0.095^{\star \star \star} \\
(0.017)\end{array}$ & & $\begin{array}{l}-0.003 \\
(0.013)\end{array}$ & & \\
\hline lagricincome & & $\begin{array}{l}0.219 * \star \star \\
(0.018)\end{array}$ & & & & $\begin{array}{l}-0.043^{\star \star \star} \\
(0.013)\end{array}$ & & $\begin{array}{l}-0.039 \\
(0.026)\end{array}$ \\
\hline ILoanamt & & $\begin{array}{c}0.001 \\
(0.019)\end{array}$ & & $\begin{array}{c}0.018 \\
(0.018)\end{array}$ & & $\begin{array}{l}0.032^{\star *} \\
(0.014)\end{array}$ & & $\begin{array}{l}0.121^{* \star *} \\
(0.027)\end{array}$ \\
\hline ILendamt & & $\begin{array}{l}-0.044 \\
(0.029)\end{array}$ & & $\begin{array}{l}-0.004 \\
(0.027)\end{array}$ & & $\begin{array}{l}0.077^{\star \star \star} \\
(0.021)\end{array}$ & & $\begin{array}{l}0.265^{\star \star \star} \\
(0.041)\end{array}$ \\
\hline ITransfers & & $\begin{array}{l}-0.095^{\star \star \star} \\
(0.018)\end{array}$ & & $\begin{array}{l}-0.061^{\star \star \star} \\
(0.017)\end{array}$ & & $\begin{array}{l}-0.045^{\star \star \star} \\
(0.013)\end{array}$ & & $\begin{array}{l}-0.074^{\star \star \star} \\
(0.025)\end{array}$ \\
\hline TTITransfer & & $\begin{array}{l}-0.101^{* *} \\
(0.040)\end{array}$ & & $\begin{array}{l}-0.098^{\star * *} \\
(0.038)\end{array}$ & & $\begin{array}{l}-0.101^{\star \star \star} \\
(0.029)\end{array}$ & & $\begin{array}{l}-0.006 \\
(0.056)\end{array}$ \\
\hline ICompensatn_wage & & $\begin{array}{l}-0.028 \\
(0.046)\end{array}$ & & $\begin{array}{c}0.050 \\
(0.043)\end{array}$ & & $\begin{array}{l}-0.185^{\star * *} \\
(0.033)\end{array}$ & & $\begin{array}{l}-0.013 \\
(0.065)\end{array}$ \\
\hline cancarryload & & $\begin{array}{l}0.845^{\star \star \star} \\
(0.117)\end{array}$ & & $\begin{array}{l}0.725^{\star \star \star} \\
(0.110)\end{array}$ & & $\begin{array}{l}0.594^{\star \star *} \\
(0.086)\end{array}$ & & $\begin{array}{l}1.129^{* \star *} \\
(0.163)\end{array}$ \\
\hline Lsize & & $\begin{array}{l}1.274^{\star \star *} \\
(0.088)\end{array}$ & & $\begin{array}{l}2.851^{\star * *} \\
(0.072)\end{array}$ & & $\begin{array}{l}-0.139 * * \\
(0.065)\end{array}$ & & $\begin{array}{l}-0.596^{\star \star \star} \\
(0.123)\end{array}$ \\
\hline Mnoeduc & & $\begin{array}{c}0.005 \\
(0.175)\end{array}$ & & $\begin{array}{c}0.094 \\
(0.165)\end{array}$ & & $\begin{array}{c}0.047 \\
(0.127)\end{array}$ & & $\begin{array}{l}-0.407^{*} \\
(0.246)\end{array}$ \\
\hline Males_in_hh & & $\begin{array}{c}0.012 \\
(0.092)\end{array}$ & & $\begin{array}{l}0.388^{\star \star \star} \\
(0.086)\end{array}$ & & $\begin{array}{l}0.414^{\star \star \star} \\
(0.066)\end{array}$ & & $\begin{array}{l}-0.437^{* \star *} \\
(0.129)\end{array}$ \\
\hline Hhsize & & $\begin{array}{l}0.101^{\star \star \star} \\
(0.021)\end{array}$ & & $\begin{array}{l}0.119 * * * \\
(0.020)\end{array}$ & & $\begin{array}{l}0.043^{\star \star \star} \\
(0.015)\end{array}$ & & $\begin{array}{l}0.110^{* \star *} \\
(0.029)\end{array}$ \\
\hline HHelectricity & & $\begin{array}{l}-0.077 \\
(0.086)\end{array}$ & & $\begin{array}{l}-0.139 * \\
(0.081)\end{array}$ & & $\begin{array}{c}0.072 \\
(0.063)\end{array}$ & & $\begin{array}{l}0.688^{\star \star \star} \\
(0.121)\end{array}$ \\
\hline ben_care4chd_orph & & $\begin{array}{l}-0.252 \\
(0.235)\end{array}$ & & $\begin{array}{l}-0.254 \\
(0.222)\end{array}$ & & $\begin{array}{c}0.288^{*} \\
(0.170)\end{array}$ & & $\begin{array}{c}0.243 \\
(0.331)\end{array}$ \\
\hline ben_handicap & & $\begin{array}{l}-0.508^{\star} \\
(0.288)\end{array}$ & & $\begin{array}{l}-0.571^{\star *} \\
(0.271)\end{array}$ & & $\begin{array}{l}-0.293 \\
(0.208)\end{array}$ & & $\begin{array}{l}-0.435 \\
(0.405)\end{array}$ \\
\hline headdecimak & & $\begin{array}{c}0.103 \\
(0.210)\end{array}$ & & $\begin{array}{c}0.033 \\
(0.198)\end{array}$ & & $\begin{array}{c}0.247 \\
(0.152)\end{array}$ & & $\begin{array}{l}-0.484 \\
(0.295)\end{array}$ \\
\hline No_beneficiaries & & $\begin{array}{c}0.088 \\
(0.097)\end{array}$ & & $\begin{array}{c}0.159^{*} \\
(0.091)\end{array}$ & & $\begin{array}{c}0.035 \\
(0.070)\end{array}$ & & $\begin{array}{l}-0.061 \\
(0.136)\end{array}$ \\
\hline self_employed & & & & & & $\begin{array}{l}-0.868^{\star \star \star} \\
(0.075)\end{array}$ & & \\
\hline Constant & $\begin{array}{l}5.031^{\star \star \star} \\
(0.104)\end{array}$ & $\begin{array}{l}1.390^{\star \star \star} \\
(0.267)\end{array}$ & $\begin{array}{l}3.696^{\star \star \star} \\
(0.101)\end{array}$ & $\begin{array}{l}0.845^{\star \star \star} \\
(0.251)\end{array}$ & $\begin{array}{l}0.486^{\star \star \star} \\
(0.058)\end{array}$ & $\begin{array}{l}0.755^{\star \star \star} \\
(0.195)\end{array}$ & $\begin{array}{l}1.840^{\star \star \star} \\
(0.111)\end{array}$ & $\begin{array}{l}1.306^{\star \star \star} \\
(0.306)\end{array}$ \\
\hline Observations & 3,008 & 3,008 & 3,008 & 3,008 & 3,008 & 3,008 & 3,008 & 3,008 \\
\hline R-squared & 0.033 & 0.490 & 0.039 & 0.526 & 0.001 & 0.108 & 0.003 & 0.093 \\
\hline \multicolumn{9}{|c|}{$\begin{array}{l}\text { Standard errors in parentheses } \\
\star \star \star * \\
*<0.01,{ }^{* *} p<0.05,{ }^{*} p<0.1\end{array}$} \\
\hline
\end{tabular}

Source: Authors' compilation.

Focusing on labour supply for agriculture, there is a negative impact of the LEAP programme. Households benefiting from the programme reduced their labour hours in agriculture by 48.9 per cent relative to non-beneficiary households in column 3. In column 4, factors like the ability to carry 
loads (cancarryload: 72.5 per cent), land size for cultivation (lsize: 285.1 per cent), having males in the household (males_in_hh: 38.8 per cent), household size (hhsize: 11.9 per cent) and the number of LEAP beneficiaries in the household (No_beneficiaries: 15.9 per cent) increased the labour supply in agriculture. On the contrary, again in Equation (4), household incomes like income from paid employment (ILabannualinc: 12.1 per cent), the sale from non-farm produce (IEnt_sales1: 9.5 per cent), transfers to households (lTransfers: 6.1 per cent) reduced household labour supply in agriculture. Being a handicapped beneficiary also reduced the labour supply by 57.1 per cent. The number of hours worked by beneficiary households in agriculture dropped by 9.8 per cent as a result of the marginal impact of transfers to a household. Transfers to the household as well as incomes received acted as a disincentive for farm work.

The impact of the LEAP programme on household labour supply for paid employment under column 6 is significant under 10 per cent. Households that had lent money to others increased their labour supply for paid employment by 7.7 per cent. The ability to carry loads, which is a measure of good health, again increased the labour supply by 59.4 per cent. Household size as well as households with male members increased a household's paid employment labour supply by 4.3 per cent and 41.4 per cent, respectively. This shows that when household members were capable, they were willing to work more hours. Beneficiaries who were care-takers of children and orphans increased their labour supply for paid employment by 28.8 per cent. On the other hand, households with non-farm enterprises (HHhasnonfarm: 22.3 per cent), income from agriculture (lagricincome: 4.3 per cent) received transfers (ITransfers: 4.5 per cent) reduced the labour supply for paid employment. The reservation wage (minimum wage that encourages household members work if they are not working) held by household members reduced household labour supply under this category by 18.5 per cent while household cultivated land size (lsize: 13.9 per cent) acted as a disincentive to work in paid employment. Households with self-employed individuals also reduced the labour supply by 86.8 per cent for paid employment.

Households hours worked in non-farm enterprises in column 8 show that households that had contracted loans (ILoanamt: 12.1 per cent), had lent to others (ILendamt: 26.5 per cent), had members who were able to carry loads (cancarryload: 112.9 per cent), electricity in the household (HHelectricity: 68.8 per cent), and larger household sizes (hhsize: 11 per cent) increased their nonfarm working hours. On the other hand, households with male membership reduced labour supply for non-farm activities by 43.7 per cent. This may primarily be due to the fact that non-farm businesses are normally female-dominated in terms of ownership and management. Cultivated land size of the household reduced involvement in non-farm work by 59.6 per cent while households where the mother of its members had no education reduced their labour supply for non-farm by 40.7 per cent. Once again, received transfers as well as income from paid employment reduced household labour supply in non-farm enterprises by 7.4 per cent and 14 per cent, respectively.

With regards to the split effect of labour supply between men and women in the household, Appendix Table A1 shows this disaggregation. We find that generally labour supply for both males and females decreased with the conditional cash transfer programme by about 66 per cent and 76 per cent, respectively, relative to the non-beneficiary households. Clearly, this should be a concern for policy as the intention of the scheme is not to create a disincentive to work. 
The study looked at the impact of the LEAP conditional cash transfer programme in Ghana on the total labour hours of households and further disaggregated the labour hours according to its focus: agriculture, paid employment and non-farm businesses. We also later disaggregated by gender. We used a difference-in-difference approach to examine the effects of the programme on the work decisions of the households to determine whether or not recipients increased or decreased the hours worked after they received benefits from the programme. Factors considered in the model were mainly household and beneficiary's characteristics.

We find that the programme decreased the total labour hours worked, specifically in agriculture, but increased labour supply for paid employment. However, there was no impact of the programme on the hours worked for non-farm businesses. Both men and women reduced their labour supply as a result of the conditional cash transfer programme.

Other factors like income from agriculture, paid employment, and sales from non-farm produce increased the total household labour supply but these same factors and transfers to a household reduced the hours worked in agriculture. Transfers to households generally reduced labour supply in total, in agriculture, in paid employment, and in the hours worked for non-farm enterprises. The health status of household members, having male members in the household coupled with larger household size and larger household cultivated land sizes increased the hours worked in agriculture. These same factors, with the exception of having males in the household, also increased the total hours committed to labour.

Households with males increased the hours worked in agriculture and in paid employment but reduced the hours worked for non-farm enterprises. Households with handicapped beneficiaries reduced the household labour supply in agriculture while households with beneficiaries who are care-givers of OVC increased the hours worked in paid employment. Households with electricity tended to increase their labour supply for non-farm enterprises.

Generally, the health of the household and household size increased the hours worked while transfers to a household reduced the household's hours of work. Ardington et al. (2009) favour transfers in the form of pension schemes, concluding that these have a positive effect on labour supply, but we find rather negative effects of the LEAP programme on the hours worked by a household.

The findings suggest that cash transfers lead to a reduction in household agricultural labour supply. This could extensively come from the fact noted by Handa et al. (2013) that children are now increasing the hours spent in school as reflected by reduced absenteeism (10 percentage points) and increased enrolment ( 7 percentage points). We believe that these children who used to supply some of the household labour have reduced the time spent contributing to family labour on the farm. Again, Handa et al. (2013) find that farmers in smaller households relied on some hired male labour after the intervention but according to our finding, this did not reduce the hours worked on the farm. Prior to the study, the use of herbicides was expected to matter to some extent, but this did not have a negative effect on household labour supply in agriculture (see Appendix Table A1).

Based on the observations above, we would suggest that subsequent targeting of transfers be 'carefully done' to produce the anticipated results. Our main reason for raising this concern is that 
the data currently being used were gathered in 2005 and are now obsolete. Once the Ghana Living Standards Survey 6 data become available, new poverty estimates should be applied so that any targeting mistakes generated by the use of old data are avoided. We also recommend the continuation of the intervention as it has a broader positive outlook for the future with regard to its goals. Expansion should be based on the new data currently being gathered so as to provide the implementers with well-informed, better determinants, such as the recipients' poverty status and the current eligibility of the households.

The impact of these programmes depends on timely cash transfers payments that are made at regular intervals so as to smooth the household consumption patterns. They should not compound consumption difficulties or be paid in lump sums as has been done in the past. There was a drift from household hours worked in farming to paid employment outside the household but whether or not the shift in labour is growth-enhancing for the overall economy is an issue researchers should look into.

\section{Appendix}

Appendix Table A1: Name of variables and their descriptions used in the study

\begin{tabular}{|c|c|}
\hline Name of variables & Description of variables \\
\hline \multicolumn{2}{|c|}{ Household characteristics } \\
\hline ILabannualinc & Log of paid employment annual income \\
\hline ILoanamt & Log of households owed amounts from contracted loans \\
\hline IEnt_sales & Log of household non-farm enterprise sales \\
\hline Lagricincome & Log of agriculture income (sale of crop, animals, rented agric lands etc.) \\
\hline ILendamt & Log of household amounts given out as loans to others \\
\hline ITransfers & Log of transfers amounts into households \\
\hline TtlTranfer & An interaction of Treattime and ITransfers \\
\hline ICompensation_wage & Log of compensation wage or reservation wage \\
\hline Self_employed & If there are self-employed household members=1; otherwise zero \\
\hline Cancarryload & If there are household members who can carry load=1; otherwise zero \\
\hline Lsize & Log of household agricultural land size \\
\hline Males_in_hh & If there are males in household=1; otherwise zero \\
\hline Mnoeduc & If the mother of household members has no education=1; otherwise zero \\
\hline Hhhasnonfarm & If household has a non-farm enterprise=1; otherwise zero \\
\hline Hhsize & Household size \\
\hline Hhelectricity & Household main source of lighting is electricity=1; otherwise zero \\
\hline ITotallabhrs & Log of overall annual household labour hours \\
\hline ITotagriclabhrs & Log of total annual household agriculture labour hours \\
\hline ITpaidemphrswk & Log of total annual household paid employment labour hours \\
\hline ITlabhrs_ent & Log of total annual household non-farm enterprise labour hours \\
\hline \multicolumn{2}{|c|}{ Charcteristics of LEAP beneficiaries } \\
\hline Ben_care4chd_orph & Beneficiary of LEAP due to being a care-giver to children or orphans \\
\hline Ben_widow & Beneficiary of LEAP due to being widowed \\
\hline Ben_handicap & Beneficiary of LEAP due to being handicapped \\
\hline
\end{tabular}


Headdecimak

No_beneficiaries

Other characteristics

Treatdum

Time2

TreatTime
Household head and main decisionmaker on LEAP transfers

Number of beneficiaries in household

Treatment $=1$ if household actually has ever received the LEAP cash transfer, zero otherwise

Time variable, where time $2=1$ if period 2 , and zero otherwise

An interaction variable between the second period and treatment

Source: Authors' compilation.

Appendix Table A2: Disaggregated effect for labour supply of households by gender

\begin{tabular}{|c|c|c|c|}
\hline & $(1)$ & $(2)$ & (3) \\
\hline VARIABLES & $\begin{array}{l}\text { Eqn9 } \\
\text { IMmen }\end{array}$ & $\begin{array}{l}\text { Eqn10 } \\
\text { IMwomen }\end{array}$ & $\begin{array}{l}\text { Eqn11 } \\
\text { IMchd }\end{array}$ \\
\hline Treatdum & $\begin{array}{l}-0.026 \\
(0.099)\end{array}$ & $\begin{array}{l}-0.312^{\star * \star} \\
(0.104)\end{array}$ & $\begin{array}{l}0.222^{\star *} \\
(0.096)\end{array}$ \\
\hline Time2 & $\begin{array}{c}0.253 \\
(0.207)\end{array}$ & $\begin{array}{l}0.554^{\star \star} \\
(0.216)\end{array}$ & $\begin{array}{c}0.111 \\
(0.200)\end{array}$ \\
\hline Treattime & $\begin{array}{l}-0.656^{\star \star \star} \\
(0.248)\end{array}$ & $\begin{array}{l}-0.755^{\star \star \star} \\
(0.260)\end{array}$ & $\begin{array}{l}-0.751^{\star \star \star} \\
(0.241)\end{array}$ \\
\hline ILabannualinc & $\begin{array}{l}-0.057^{\star * *} \\
(0.022)\end{array}$ & $\begin{array}{l}-0.019 \\
(0.022)\end{array}$ & $\begin{array}{l}-0.020 \\
(0.021)\end{array}$ \\
\hline HHhasnonfarm & $\begin{array}{c}0.125 \\
(0.155)\end{array}$ & $\begin{array}{c}0.230 \\
(0.163)\end{array}$ & $\begin{array}{c}0.245 \\
(0.151)\end{array}$ \\
\hline IEnt_sales1 & $\begin{array}{l}-0.055^{\star \star \star} \\
(0.015)\end{array}$ & $\begin{array}{l}-0.070^{\star \star \star} \\
(0.016)\end{array}$ & $\begin{array}{l}-0.029 * \\
(0.015)\end{array}$ \\
\hline lagricincome & $\begin{array}{l}0.185^{\star * *} \\
(0.016)\end{array}$ & $\begin{array}{l}0.177^{\star \star *} \\
(0.017)\end{array}$ & $\begin{array}{l}0.108^{\star * \star} \\
(0.016)\end{array}$ \\
\hline ILoanamt & $\begin{array}{l}-0.004 \\
(0.016)\end{array}$ & $\begin{array}{l}-0.004 \\
(0.017)\end{array}$ & $\begin{array}{l}-0.002 \\
(0.016)\end{array}$ \\
\hline ILendedamt & $\begin{array}{l}-0.035 \\
(0.025)\end{array}$ & $\begin{array}{l}-0.079 * * * \\
(0.026)\end{array}$ & $\begin{array}{c}0.002 \\
(0.024)\end{array}$ \\
\hline ITransfers & $\begin{array}{l}-0.077^{\star \star \star} \\
(0.015)\end{array}$ & $\begin{array}{l}-0.030 * \\
(0.016)\end{array}$ & $\begin{array}{c}0.025^{\star} \\
(0.015)\end{array}$ \\
\hline TTITransfer & $\begin{array}{c}0.042 \\
(0.034)\end{array}$ & $\begin{array}{c}0.002 \\
(0.036)\end{array}$ & $\begin{array}{c}0.024 \\
(0.033)\end{array}$ \\
\hline ICompensatn_wage & $\begin{array}{l}0.081^{\star *} \\
(0.039)\end{array}$ & $\begin{array}{l}-0.009 \\
(0.041)\end{array}$ & $\begin{array}{c}0.020 \\
(0.038)\end{array}$ \\
\hline cancarryload & $\begin{array}{c}0.096 \\
(0.099)\end{array}$ & $\begin{array}{l}0.400^{\star \star \star} \\
(0.104)\end{array}$ & $\begin{array}{c}0.045 \\
(0.096)\end{array}$ \\
\hline Isize & $\begin{array}{l}1.218^{\star \star \star} \\
(0.083)\end{array}$ & $\begin{array}{l}1.006^{\star \star \star} \\
(0.086)\end{array}$ & $\begin{array}{l}0.383^{\star \star \star} \\
(0.080)\end{array}$ \\
\hline Mnoeduc & $\begin{array}{c}0.062 \\
(0.148)\end{array}$ & $\begin{array}{c}0.110 \\
(0.154)\end{array}$ & $\begin{array}{l}-0.029 \\
(0.143)\end{array}$ \\
\hline males_in_hh & $\begin{array}{l}1.499^{\star \star \star} \\
(0.077)\end{array}$ & $\begin{array}{l}-0.503^{\star \star \star} \\
(0.081)\end{array}$ & $\begin{array}{l}-0.192^{\star *} \\
(0.075)\end{array}$ \\
\hline
\end{tabular}




\begin{tabular}{|c|c|c|c|}
\hline hhsize & $\begin{array}{l}0.101^{\star \star \star} \\
(0.018)\end{array}$ & $\begin{array}{l}0.117^{\star \star \star} \\
(0.018)\end{array}$ & 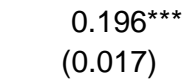 \\
\hline HHelectricity & $\begin{array}{l}-0.124^{*} \\
(0.073)\end{array}$ & $\begin{array}{l}-0.184^{* *} \\
(0.076)\end{array}$ & $\begin{array}{l}-0.022 \\
(0.070)\end{array}$ \\
\hline ben_careforchd_orphans & $\begin{array}{l}-0.101 \\
(0.198)\end{array}$ & $\begin{array}{l}-0.039 \\
(0.207)\end{array}$ & $\begin{array}{c}0.375^{\star} \\
(0.192)\end{array}$ \\
\hline ben_handicap & $\begin{array}{l}-0.622^{\star \star} \\
(0.242)\end{array}$ & $\begin{array}{l}-0.234 \\
(0.253)\end{array}$ & $\begin{array}{c}0.059 \\
(0.235)\end{array}$ \\
\hline headdecimak & $\begin{array}{c}0.291 \\
(0.177)\end{array}$ & $\begin{array}{c}0.303 \\
(0.185)\end{array}$ & $\begin{array}{c}0.143 \\
(0.172)\end{array}$ \\
\hline No_beneficiaries & $\begin{array}{l}-0.047 \\
(0.081)\end{array}$ & $\begin{array}{c}0.095 \\
(0.085)\end{array}$ & $\begin{array}{c}0.121 \\
(0.079)\end{array}$ \\
\hline IHired & $\begin{array}{l}0.117^{\star \star \star} \\
(0.018)\end{array}$ & $\begin{array}{l}0.229 * \star \star \\
(0.019)\end{array}$ & $\begin{array}{l}0.053^{\star * *} \\
(0.018)\end{array}$ \\
\hline Herbicide & $\begin{array}{l}0.397^{\star \star \star} \\
(0.113)\end{array}$ & $\begin{array}{l}0.418^{\star \star \star} \\
(0.118)\end{array}$ & $\begin{array}{l}0.398^{\star \star \star} \\
(0.109)\end{array}$ \\
\hline TtlHired & $\begin{array}{l}0.156^{\star \star \star} \\
(0.039)\end{array}$ & $\begin{array}{l}0.207^{* * *} \\
(0.041)\end{array}$ & $\begin{array}{c}0.050 \\
(0.038)\end{array}$ \\
\hline TTherbicide & $\begin{array}{l}-0.251 \\
(0.259)\end{array}$ & $\begin{array}{l}-0.034 \\
(0.271)\end{array}$ & $\begin{array}{l}-0.235 \\
(0.251)\end{array}$ \\
\hline Constant & $\begin{array}{l}-0.198 \\
(0.225)\end{array}$ & $\begin{array}{c}0.359 \\
(0.236)\end{array}$ & $\begin{array}{l}-0.670 \text { *** } \\
(0.218)\end{array}$ \\
\hline Observations & 3,008 & 3,008 & 3,008 \\
\hline $\begin{array}{l}\text { R-squared } \\
\text { Standard errors in parentheses } \\
\star \star \star \\
p<0.01,{ }^{* \star} p<0.05,{ }^{*} p<0.1\end{array}$ & 0.561 & 0.471 & 0.209 \\
\hline
\end{tabular}

Source: Authors' compilation.

\section{References}

Aguero, J.M., M.R. Carter, and I. Woolard (2007). 'The Impact of Unconditional Cash Transfers on Nutrition: The South African Child Support Grant'. Working Paper. Brasilia: International Policy Centre for Inclusive Growth.

Ardington, C., A. Case, and V. Hosegood (2009). 'Labour Supply Responses to Large Social Transfers: Longitudinal Evidence from South Africa'. American Economic Journal, 1(1): 22-48.

Attanasio, O., and A. Mesnard (2006). 'The Impact of a Conditional Cash Transfer Programme on Consumption in Colombia'. Fiscal Studies, 27(4), 421-42.

Bertrand, M., M. Sendhil, and D. Miller (2003). 'Public Policy and Extended Families: Evidence from Pensions in South Africa'. World Bank Economic Review, 17(1): 27-50.

Brewin, M. (2008). 'Evaluation of Concern Kenya's Kerio Valley Cash Transfer Pilot'. Technical Report. Concern Kenya. London: ALNAP. Available at: www.alnap.org/resource/6176.aspx

Cunha, J. (2010). 'Testing Paternalism: Cash vs. In-Kind Transfers in Rural Mexico'. Technical Report. Stanford, CA: Stanford University. Available at: www.frbsf.org/economicresearch/files/ TestingPaternalism_JesseCunha.pdf 
Daily Graphic (2012). www.graphic.com, 15 March 2012.

Duflo, E. (2003). 'Grandmothers and Granddaughters: Old-Age Pensions and Intra-household Allocation in South Africa'. World Bank Economic Review, 17(1): 1-25.

Ferro, A.R., A.L. Kassouf, and D. Levison (2010). 'The Impact of Conditional Cash Transfer Programmes on Household Work Decisions in Brazil'. In R.K.Q. Akee, E.V. Edmonds and K. Tatsiramos (eds), Child Labour and the Transition between School and Work (Research in Labour Economics, Volume 31). Bingley: Emerald Group Publishing Limited.

Gertler, P. (2004). 'Do Conditional Cash Transfers Improve Child Health? Evidence from Progresa's Control Randomized Experiment'. American Economic Review Papers and Proceedings, 94(2): 336-41.

Gertler, P., S. Martinez, and M. Rubio-Codina (2006). 'Investing Cash Transfers to Raise Long-term Living Standards’. Policy Research Working Paper 3994. Washington, DC: World Bank.

Handa, S., M. Park, I. Osei Akoto, R. Darko Osei, B. Davis, and S. Diadone (2013). 'Livelihood Empowerment against Poverty Programme Impact Evaluation'. Chapel Hill: University of North Carolina, Carolina Population Center. Available at: http://www.unicef.org/ghana/gh_resources_LEAP_Quant_impact_evaluation_FINAL_OCT _2013.pdf

Humphries, R. (2008). 'Periodical Review of the Cash Transfers for Development Project'. Technical Report. Oxfam Great Britain in Viet Nam. Available at. www.mtnforum.org/sites/default/files/publication/files/6403.pdf

Maluccio, J.A., and R. Flores (2005). 'Impact Evaluation of a Conditional Cash Transfer Programme: The Nicaraguan Red de Protección Social'. Research Report 141. Washington, DC: IFPRI.

National Social Protection Strategy (NSPS) (2007). 'Investing in People'. Available at: http://www.ipc-undp.org/doc_africa_brazil/Ghana.pdf (accessed June 2014).

Oliveira, A.M.H. et al. (2007). 'Primeiros Resultados da Análise da Linha de Base da Pesquisa de Avaliação de Impacto do Programa Bolsa Família'. In J. Vaitsman, and R. Paes-Souza (eds), Avaliação de Políticas de Programas do MDS - Resultados, Volume 2. Brasília: SAGI/MDS.

Paxson, C., and N. Schady (2007). 'Does Money Matter? The Effects of Cash Transfers on Child Health and Development in Rural Ecuador'. Policy Research Working Paper 4226. Washington, DC: World Bank.

Posel, D., A.F. James, and L. Frances (2006). 'Labour Migration and Households: A Reconsideration of the Effects of the Social Pension on Labour Supply in South Africa'. Economic Modelling, 23(5): 836-53.

Rawlings, L., and G. Rubio (2003). 'Evaluating the Impact of Conditional Cash Transfer Programmes: Lessons from Latin America'. Washington, DC: World Bank.

Rubalcava, L., G. Tereul, and T. Duncan (2004). 'Spending, Saving, and Public Transfers Paid to Women'. Working Paper Series CCPR-024-04. Los Angeles, CA: UCLA, California Center for Population Research.

Sadoulet, E., A. Janvry, and B. Davis (2001). 'Cash Transfer Programmes with Income Multipliers: PROCAMPO in Mexico'. World Development, 29(6): 1043-56. 
Samson, M., U. Lee, A. Ndlebe, K. Mac Quene, I. van Niekerk, V. Ghandi, T. Harigaya, and C. Abrahams (2004). 'The Social and Economic Impact of South Africa's Social Security System'. Commissioned by the Department of Social Development. Cape Town: EPRI

Schultz, T. P. (2004). 'School Subsidies for the Poor: Evaluating the Mexican Progresa Poverty Programme'. Journal of Development Economics, 74(1): 199-250.

Skoufias, E., and V. D. Maro (2008). 'Conditional Cash Transfers, Adult Work Incentives, and Poverty.' Journal of Development Studies, 44(7): 935-60.

Skoufias, E., and S. Parker (2001). 'Conditional Cash Transfers and their Impact on Child Work and Schooling: Evidence from the Progresa Programme in Mexico'. Economia, 2(1): 45-94.

Slater, R., and M. Mphale (2008). 'Cash Transfer, Gender, and Generational Relations: Evidence from a Pilot Project in Lesotho'. London: Overseas Development Institute. Available at: www.odi.org.uk/sites/odi.org.uk/files/odi-assets/publications-opinion-files/2574.pdf 